\title{
FALKLAND ISLANDS AND DEPENDENCIES
}

Area: 16,265 sq. . km

Population: 1900

Capital: Port Stanley

Civil Commissioner: Sir Rex M. Hunt

The Falklands (Islas Malvinas) comprise East Falkland (Soledad), West Falkland (Gran Malvina), South Georgia (Georgia del Sur) and a number of small islands.

The Falkland Islands Police Force is very small, as befits a territory with very little crime. Most of its personnel are quartered at Port Stanley, but there is a detachment in South Georgia. Police officers are, with few exceptions, recruited locally.

As a result of the 1982 conflict between the UK and Argentina, the former maintains a large military force in the Falklands under a Military Commissioner. This includes a Military Police unit.

Falkland Islands Police Office, Port Stanley (95) 